\title{
E. Kloppers
}

\section{TYD AS GAWE - GOD SE TYD: DIE POLSSLAG VAN DIE KERKJAAR}

TIME AS A GIFT - GOD'S TIME: THE RHYTHM OF THE CHURCH YEAR

\begin{abstract}
When seen as a gift - as God's time - the careful shaping of the church year strengthens the celebratory character of the worship service; contributes to the effective proclamation of the Word; underlies the church's confession; introduces new people and young people to the faith; forms community; adds to comforting people; exerts healing; anchors the church's diaconal work; contributes to missionary proclamation to "outsiders"; and reflects the ecumenical character of the church service. This article is a plea for a greater consciousness for the structure and times of the church year, with a view to the conveyance of the full truth of the Gospel and the formative effect in the life of the community of faith.
\end{abstract}

\section{INLEIDING: 'N VERSKRAALDE BEWUSSYN VAN DIE KERKJAAR}

'n Verskraalde bewussyn van die Kerkjaar was tot ongeveer 'n eeu gelede 'n kenmerk van reformatoriese kerke wêreldwyd. 'n Voorbehoud is in 'n groot mate veroorsaak deur 'n oordrewe vrees vir "ritualisme" en "katolisisme". Die vaste orde van die Kerkjaar is gesien as ' $n$ binding op die werk van die Heilige Gees en 'n aantasting van die vryheid van die prediker om na eie goeddunke elke erediens "onder leiding van die Gees" in te rig. Liturgiese bewegings in

Dr. Elsabé Kloppers, Navorsingsgenoot Departement Praktiese Teologie, Fakulteit Teologie, Universiteit van die Vrystaat.E-pos: iksa@absamail.co.za 
verskeie lande (kyk onder meer Klöckener \& Kranemann 2002) het egter teen die einde van die negentiende en begin twintigste eeu die belang van die Kerkjaar téénoor die willekeur van individue begin beklemtoon. In Nederland oefen die Liturgische Beweging diepgaande invloed uit om 'n groter bewussyn vir die Kerkjaar te weeg te bring. Dit dra by tot die kerkliedrepertorium in Nederland soos onder meer in die Liedboek voor de Kerken (Interkerkelijke Stichting voor het Kerklied: 1973). In die Church of Scotland (om 'n verdere voorbeeld te noem) het die afgelope paar jaar ook 'n groter bewussyn vir die Kerkjaar ontwikkel. Tog is daar steeds dieselfde vrees vir "katolisisme" en "ritualisme", wat onder meer neerslag vind in 'n onwilligheid om byvoorbeeld die Ons Vader hardop saam te bid, in sommige kringe ' $n$ vooroordeel teen die gebruik van kerse, en 'n voorbehoud ten opsigte van die "vastheid" van die Kerkjaar (soos blyk uit gesprekke met lidmate en predikante gedurende 'n tydperk van Junie tot Augustus 2010).

'n Verskraalde bewussyn vir die Kerkjaar was tot so onlangs as tien, vyftien jaar gelede ook 'n kenmerk van die Afrikaanse susterkerke. Oor die jare is die "hooffeeste", soos Kersfees en Paasfees gevier, maar as losstaande entiteite en nie as vieringe binne ' $n$ breër geheel wat ' $n$ bepaalde verband met mekaar het en saam 'n bepaalde struktuur vorm nie. As gevolg van 'n bewusmakingsproses die afgelope paar jaar het die situasie in sommige gemeentes verander - in die NG Kerk veral vanweë die werk vanuit BUVTON en in die Nederduitsch Hervormde Kerk deur die Instituut vir Kerkmusiek in SA. In vele gemeentes in dié kerke is die patroon egter steeds onveranderd en duur dieselfde frustrasies voort. Die afwisseling wat die verskillende tye in die Kerkjaar bied word nie benut nie en dieselfde temas, skrifgedeeltes en liedere word oor en oor gehoor, sodat die erediens in eentonigheid verval. Die lied kry ook meestal die skuld vir alles wat in die erediens geyk en verstar sou wees, terwyl die bron van verstarring primêr elders lê: in 'n verskraalde bewussyn vir die Kerkjaar.

In die Afrikaanssprekende kerke het die bewusmakingsproses nog maar pas begin. Die situasie verskil dus ingrypend van byvoorbeeld die kerke in Nederland, waar ' $n$ bewusmakingsproses oor bykans 'n eeu reeds plaasgevind het. 'n Nederlandse teoloog ondersoek die werk van die Liturgische Beweging in Nederland fenomenologies en kondig aan: "We zijn de Liturgische Beweging voorbij" (Barnard 2006:31), omdat hy meen dat die Beweging die kerk en die erediens in ' $n$ vaste vorm wou indruk wat indruis teen die huidige konteks en atmosfeer in die samelewing. ${ }^{1}$ Hierdie bevindinge

1 As voorbeeld van invloede uit die huidige tydsgees sluit Barnard aan by die vooroordeel van groepe met ' $n$ meer charismatiese oriëntering, soos by Praise and Worship, wat struktuurloosheid ten opsigte van die "liturgiese orde" voorstaan en ook die Kerkjaar as te bindend beskou. Myns insiens word nie genoegsaam aangetoon 
kan nie lynreg op die Suid-Afrikaanse situasie toepaslik gemaak word nie in vele gemeentes is daar nog nie eens ' $n$ begin gemaak nie.

In verskeie studies het ek ook reeds vroeër die invloed van die huidige konteks en tydsgees, wat as postmodern of laat-modern beskryf kan word, op die erediens en die kerklied ondersoek (Kloppers 1997; 2003a; 2003b) en onder meer getoon hoe daar in 'n era van radikale individualisme steeds ' $n$ behoefte aan gemeenskap, sowel as gemeenskaplike vormgewing en struktuur blyk te wees, asook hoe oënskynlik negatiewe tendense teologies nuut gevul kan word. Die doel van hierdie artikel is nie om omvattend op die tendense in die huidge tydsgewrig uit te brei nie. Die bedoeling is ook nie om die Kerkjaar as fenomeen te ondersoek, om in te gaan op die herkoms van die Kerkjaar, of om die probleme ten opsigte van die funksionering van 'n Kerkjaar wat in die noordelike halfrond ontstaan het te vergelyk met die funksionering daarvan in die suidelike halfrond nie. Dit sou te omvattend raak. Met hierdie artikel word eerder gepoog om op 'n gestruktureerde wyse - wat nie só in bestaande literatuur gevind kan word nie - 'n pleidooi te lewer vir 'n groter bewussyn in die Suid-Afrikaanse kerke en breër, vir die struktuur en tye van die Kerkjaar, en te toon hoe 'n uitleef van die Kerkjaar nuut of opnuut kan bydra tot die uitdra en voortgang van die Christelike geloof te midde van 'n gesekulariseerde samelewing - verkondiging dus deur middel van die Kerkjaar met die oog op die "volle rykdom van die boodskap van Christus" (Kolossense 3) en die vormende werking daarvan in die voortgaande lewe van die geloofsgemeenskap en die lewe na buite. Die gestaltegewing van die Kerkjaar as geskenkte tyd, as God se tyd, versterk die vieringskarakter van die erediens, dra by om die Woord meer effektief te verkondig, die belydenis te dra, jongmense en nuwelinge in die geloof in te lei, koinonia te bewerkstellig, mense te vertroos, heling te bewerk, die kerk se dienswerk te anker, missionêr na buite te verkondig, die geloof uit te dra, en die erediens se ekumeniese karakter te versterk.

\section{DIE STRUKTUUR VAN DIE KERKJAAR}

Die uitgangspunt van die geloof en vieringe van die kerk van Christus is die Opstanding (Sauter 1993:56-68). Die gemeente leef daagliks die erediens van die lewe en kom reëlmatig weer in die gesamentlike byeenkoms van die gelowiges op die Sondag, die dag van die opstanding saam (Lukas 24:13;

dat hierdie sienings vanuit die opwekkingsbewegings in die negentiende eeu as voorgangers van Praise and Worship reeds langer as honderd jaar in omgang is en dat die invloed vanuit hierdie oriënterings dus nie bloot ' $\mathrm{n}$ nuwe, eietydse fenomeen is waardeur die bestaan en voortgang van die Liturgische Beweging bevraagteken kan word nie, maar dat die Liturgische Beweging juis ook teen die vooroordeel van hierdie groepe in wou werk. 
Johannes 20:19-26; Handelinge 20:7). Die viering van Sondag tot Sondag vorm dus die ritme, die asemhaling waarmee die kerk leef - dit is die "weeklikse pase" (Van Tongeren 2001:73). Elke erediens en alle samekomste van die gelowiges staan egter altyd óók in 'n bepaalde tyd in die Kerkjaar, wat deur kerke wêreldwyd in meerdere of mindere mate gevolg word (Webber 1994:374). Die gemeente vier dus altyd die ontmoeting met die opgestane Heer, maar met verskillende klemtone in die verskillende tye van die jaar (Saliers 1993:103-110).

Die Kerkjaar het 'n geskakeerde patroon wat in die loop van die eeue, naas alle konstante, ook variasie vertoon. Die middelpunt vir die kerk was en is die Paasfees, die drie dae vanaf Goeie Vrydag tot Paassondag (Saliers 1994:93). In die Afrikaanse susterkerke word aangesluit by 'n ekumeniesliturgiese tradisie van die Kerkjaar in vereenvoudigde vorm (vgl Nederduitse Gereformeerde Kerk 2007 en Nederduitsch Hervormde Kerk 2008). Tye in die jaar wat gevier word, word in drie groot tye ingedeel:

- Die Kerskring bestaan uit Advent (vier weke); Kersfees; Epifanie (6 Januarie) en die Epifanietyd

- Die Paaskring bestaan uit die Lydenstyd (in baie tradisies bekend as die Veertigdagtyd), wat begin op Aswoensdag, Palmsondag, Stil week, Witte Donderdag (in die Nederlandse Kerke) of Gründonnerstag (in die Duitse Lutherse Kerke) ${ }^{2}$ voorafgaande aan Goeie Vrydag, die dae van Pase (Goeie Vrydag, Stil Saterdag en Paassondag of Opstandingsondag), die ses Sondae van die Opstanding en Pinkster, die vyftigste Paasdag. Paasfees, Hemelvaart ( $40^{\text {ste }}$ dag van die Opstanding) en Pinkster word as een samehangende geheel beskou. ${ }^{3}$

$2 \quad$ Die Kerk leef hier die siening van die Bybelse tyd na dat ' $n$ dag met sonsondergang begin (Monshouwer 1998:114-115; 124), daarom is die Donderdagaand as die vooraand van Goeie Vrydag dus eintlik die moment waarop Paasfees begin. Heel gepas vier baie gemeentes in die Afrikaanse kerke ook reeds vir ' $n$ aantal jare die Nagmaal op die Donderdagaand voorafgaande aan Goeie Vrydag as viering van die instelling van die Nagmaal.

3 In voorstelle ter vernuwing van die Kerkjaar, dui die Liturgische Konferenz (2005:23) eerder 'n "Vier-Felder-Schema" aan waarbinne Pinkster "nicht wie bisher als Abschluss des Osterfestkreise aufgefasst werden, sondern als eigene Sequenz innerhalb des Festzyklus." Dit loop dan van die Sondag ná Pinkstersondag tot Johannistag op 24 Junie, met "liturgische und homiletische Freiräume" wat gevul word deur besondere temas of gemeentespesifieke sake, tot met Michaelisdag aan die einde van September. Die vierde feessekwens word as die "Späte Zeit des Kirchenjahres" aangedui, met Dankdag vir die oes, Reformationstag en dies meer, tot met Toten-/Ewigkeitssonntag. Vir ons doeleindes kan die Pinkstertyd strek vanaf Pinkstersondag tot einde September, waartydens die werk van die Heilige Gees, die volheid van God (Drie-eenheid), Skepper en skepping, en dies 
- Pinkstertyd of Koninkryktyd na Drie-eenheidsondag tot die einde van die Kerkjaar.

Die bepaalde tyd in die Kerkjaar bepaal die aard, tema en inhoud van 'n spesifieke erediens. Daarby hoort skriflesings, lesings, liedere en visuele middele wat by die bepaalde tyd pas. Hiermee gaan die preek en breër verkondiging gepaard, waar perspektief gegee word op konkrete gebeure in die gemeente; op gebeure in die wêreld op die besondere tydstip (Earey \& Myers 2001:230-233); en in lidmate se lewe, deur die besondere ontmoeting met God op daardie oomblik in die erediens. Kennis van die struktuur van die Kerkjaar, sowel as die doel en funksie van die Kerkjaar, is dus onontbeerlik.

\section{DIE DOEL EN FUNKSIES VAN DIE KERKJAAR}

\subsection{Die Kerkjaar het 'n liturgiese of vieringsfunksie}

Die Kerkjaar of liturgiese jaar dui op die ordening van die tyd in die liturgie. Dit is die "Feier des Heils in der Zeit" (Richter 1982:17). Die Kerkjaar het vanuit die Bybelse geskrifte gegroei in aansluiting by die groot feeste van Israel wat geleenthede was om te vertel en te hervertel (Monshouwer 1998:99-123). So bied die viering van die feeste in die Kerkjaar ook die geleentheid om die singewende verhale vanuit die sentrale gebeurtenis van Jesus Christus se sterwe en opstanding ordelik te vertel en te hervertel en telkens weer te herdenk. Hierdie herdenking van die gebeure uit die verlede het transformatiewe krag vir die hede en die toekoms. In die liturgie, in die 'hervertel' oftewel 'naspeel' van gebeure kry mense in die hier en nou deel aan die gebeure, met die oog op die toekoms:

Verleden, heden en toekomst spelen hier dooreen. In het ritueel van de Maaltijd word dat bijvoorbeeld duidelijk: door het eeuwenoude verhaal van Jezus' laatste maaltijd ... opnieuw te vertellen en te verbeelden, krijgt men als het ware nú deel aan dat gebeuren. ... In dit 'spel' met de tijd grijpen herinnering (anamnese) en verwachting in elkaar. [Só] definiëren degenen die deelnemen aan het ritueel zichzelf as mensen

meer ter sprake kan kom. Koninkryktyd loop dan vanaf Oktober met biddag vir die gesaaides/ dankdag vir die oes; die werk en uitbreiding van die kerk; Hervormingsondag; Eskatologie/ die weerkoms van Christus; die eindoordeel, die ewige lewe en Ewigheidsondag (Herdenking van afgestorwe geliefdes oftewel voorgangers in die geloof). 
die op weg zijn tussen schepping en voleinding... (Van Leeuwen 1998:57-58)

Die viering in die Kerkjaar maak dit moontlik om te vertel, beeldend te vertel, altyd weer te vertel en die essensie van die grootverhale uit die verlede teenwoordig te stel. So kry mense wat deelneem aan die liturgie telkens opnuut in die hede deel aan dit wat in die verlede gebeur het - dus nie bloot as toeskouers nie, maar as aktiewe deelnemers wat altyd weer deel kry aan die gebeure. Deur die viering in die hede, word die geloofsgemeenskap gehelp om hulle eie lewens in die lig van die begrondingsverhale of singewende verhale te sien en daardeur getransformeer te word.

In 'n beskrywing van die viering van die Kerkjaar met jongmense word beskryf hoe hulle besef het dat die Festgeheimnis hulle eie lewe tot spreke bring en dit nuut maak. In die uitbeelding byvoorbeeld van die kruisweg gedurende die Lydenstyd, het die jongmense ontdek dat hulle hul eie lewe sigbaar naspeel. So het hulle hulself ontmoet, hulself herken vir wie hulle werklik is en is daardeur verander: "Sie haben ihre eigene Erlösungsbedürttigkeit gespielt und darin zugleich etwas von Erlösung erfahren" (Grün \& Reepen 1985:7).

\subsection{Die Kerkjaar het 'n verkondigingsfunksie}

Saliers (1994) beskryf die Kerkjaar as 'n fundamentele kenmerk van outentieke aanbidding, wat van die begin-af deel was van die Joodse en Christelike ervaring. Tyd is wesenlik aan die geloof self omdat God se self-openbaring histories en temporeel is. Die gebeure waardeur die lewende God met die mens kommunikeer is historiese gebeure: "... remembering and proclaiming those events are at the heartbeat of all preaching and worship" (Saliers 1994:92).

Die onderliggende narratief van die erediens is die "Gospel Story" (Long 2001:43). Deur die verkondiging van die geloofsverhaal vanuit die Kerkjaar as grondstruktuur, word die verhaal van die openbaring elke jaar opnuut en so omvattend moontlik na vore gebring. Dié struktuur bied die geleentheid om alle dimensies van die geloof en die volheid van die geloof ter sprake te bring, ooreenkomstig Kolossense 3:16: "Die boodskap van Christus moet in sy volle rykdom in julle bly."

In die eerste deel van die Kerkjaar word sistematies aan die lewe, sterwe en opstanding van Jesus Christus aandag gegee. Verder kom die uitstorting en teenwoordigheid van die Heilige Gees, die Drie-eenheid, gawes van die Gees, God se werk in die skepping, ons verantwoordelikheid, die werk van die Kerk, die groei van die Koninkryk van God, die opbou van die gemeente, 
onderlinge verhoudings, dienswerk, God se toekoms en die verwagting van die wederkoms in die tweede deel van die Kerkjaar onder meer ter sprake. Die einde van die Kerkjaar staan in die teken van jaareinde, afskeid van geliefdes in die jaar, die wederkoms of eskatologie. Deur by die Kerkjaar te hou word dus voorkom dat 'n predikant struktuurloos by ' $\mathrm{n}$ eie voorkeur aan Bybelgedeeltes, temas en liedere vassteek. Volgens Sauter (1993:66) is die uitleef van die Kerkjaar die beste teenwig teen 'n eensydige teologie, as sou teologie uit één tema met variasies bestaan, soos ' $n$ teologie van die skepping, of teologie van die liefde, of teologie van die kruis.

Deur die verskillende tye in die Kerkjaar simbolies in te klee met verkondiging wat deur die woord, maar ook deur musiek, en visueel deur middel van simbole, kleur en beelde geskied, word die Woord verkondig deur variasie én 'n geheel van kommunikasie op verskillende vlakke. So word die wesenlike van ons geloof binne die verloop van tyd verkondig en sigbaar gemaak - tot gestalte gebring. Die Kerkjaar bied dus die basis en struktuur vir verskeidenheid en volheid in die verkondiging.

\subsection{Die Kerkjaar het 'n kategetiese funksie.}

God se Woord word deur ' $n$ veelheid van handelinge en simbole in die liturgie, soos die preek, die sang, gebede en belydenisse gesimboliseer oftewel vergestalt. Deur hierdie verskeidenheid van vorme leer kinders (en "reedsgelowiges") die geloofswaarhede en maak dit as't ware spelend hul eie. In die uitbeelding deur die Kerkjaar word hierdie volheid van ons geloof sigbaar en hoorbaar aan mekaar, aan ons kinders, én aan nuwelinge in die geloof oorgedra. Hierdie toe-eiening geskied op 'n logiese en ordelike manier oor die tyd. Heel gepas merk Luther (WA XXVI 1983:223) op: “... man kann nicht alle Stücke des Evangeliums auf einmal lehren..."

Die kategetiese funksie sluit dus by die viering-, sowel as verkondigingsfunksie aan, maar is meer gerig op diegene wat nog in die geloof ingelei word. In die omgang met die erediens is die leer-verstaan nie die belangrikste nie, maar die sosialisering, met ander woorde die meemaak, deurslaggewend. Dit het veral betekenis vir die religieuse sosialisasie van kinders: "Im Grunde müßten sie mit dem Gottesdienst aufwachsen, von Anfang an" (Daiber 1992:18).

Hieruit blyk duidelik dat die erediens die belangrikste en eerste plek is om geloofswaarhede toe te eien. Sogenaamde kinderdienste waar die verloop van die Kerkjaar en die liedere vir die tyd in die Kerkjaar geen aandag kry nie, moet dus bevraagteken word, te meer as ook in ag geneem word dat die ervaring van tyd in en rondom die erediens ten nouste verband hou met kinders se sosiale en emosionele ontwikkeling (Heimbrock 1993:63-66). 


\subsection{Die Kerkjaar dra die belydenis}

"Der Glaube braucht das Fest. Das Fest nährt den Glauben" (Cornehl, Dutzmann \& Strauch 1993:7). In die feeste in die Kerkjaar word die struktuur en inhoud van die geloof duidelik. In hierdie feesvierings tree die geloof in verskyning. Die Kerkjaar bied dus die onderliggende struktuur wat die inhoud van ons belydenis dra en wat die aard en inhoud van elke Sondag se erediens bepaal. "The faith of the church from its beginnings manifests in its pattern of worship over time an implicitly Trinitarian structure (Saliers 1994:03). Mönnich (1966) vergelyk die siklus van die feeste met die opsomming van Christus se bestaan in die tweede artikel van die geloofsbelydenis (credo) en toon hoedat dit wat daarin genoem word ooreenstem met die feeskring:

Wat ontvang is van die Heilige Gees, gebore uit die maagd Maria' - dit is Kersfees. 'Wat gely het onder Pontius Pilatus, gekruisig is, gestorwe en begawe is' - dit gedenk ons in die Lydenstyd. Met 'op die derde dag opgestaan het uit die dood', gedenk ons Paasfees' (Mönnich 1966:103104).

Die tyd van die liturgie en die tyd van die Kerkjaar is nie lineêr-historiese tyd nie, maar kwalitatief gevulde tyd - tyd gevul deur die beslissende gebeure van die openbaring. Bakker (1996:295) verwys na die teologiese tydsleer van Karl Barth en dié se verwysing na die Tyd van Herinnering en die Tyd van Verwagting, met daartussen as 'n telkens nuwe hede: God-met-ons. Dit is die moment waarop ons deur herinnering en verwagting gelyktydig word met die ervaring van God se teenwoordigheid en dit ook bely.

Die Kerkjaar bied dus die struktuur waarbinne die geloofsgemeenskap telkens geloofsverhale nuut vertel en nuut hóór, altyd opnuut deelkry aan, en deel word van die geloofswerklikheid. Saam met en deur die návertel word ook bely. Binne hierdie belydende struktuur word die handelinge in elke erediens in die Kerkjaar telkens nuut, maar ordelik gestruktuur om die geloofsboodskap ook opnuut vir 'n bepaalde Sondag die beste te verkondig, en van hieruit as gemeenskap én as individu die geloof te bely.

\subsection{Die Kerkjaar het 'n pastorale of antropologiese funksie}

In die hoofstuk oor 'symbolisch gebrochene Endlichkeit. Ritual und Zeit' wys Heimbrock (1993:60-80) daarop dat so ver as wat ons in die kultuur- en godsdiensgeskiedenis kan terugkyk, daar getuienis daarvoor is dat die omgang met die tyd as 'n grondliggende menslike opdrag ervaar is. Tyd behoort tot ons fundamenteelste lewensvoorwaardes. Ons is deur die mees elementêre liggaamservarings aan die tyd verbonde. Ons ervaar ons polsslag, ons in- en 
uitasem as biologiese ordeninge in die tyd; ons wakker- en slaaptye hang met die ritme van die dag en die nag saam. Ons het 'n bewussyn van die tye in die week en van die tye in die jaar. Verstorings van hierdie tydsbewussyn en tydsgrense kan mense ernstig siek maak. 'n Logiese verloop van tyd én die sinvolle vulling van tyd, hou mense egter gesond en bring heling - die conditio humana staan op die spel (Bieritz 2003:389).

"Das, was im Gottesdienst gefeiert wurde, stand seiner Intention nach im Zusammenhang mit der Zeit, mit ihrer Ordnung..." (Heimbrock 1993:61). Vanuit die onlosmaaklike verbinding tussen erediens en tyd, bied die erediens by uitstek die ruimte aan mense om hulleself te distansieer van die vervreemding wat in die alledaagse as gevolg van maatskaplike faktore en dwang ervaar word: “... sie bietet ein Stück 'Gegenwelt' an” (Heimbrock 1993:66). Die christelike geloof en fees het die oorwinning en terselfdertyd die verandering van die alledaagse as oogmerk (Schilson 1994:29).

Die erediens bied die geleentheid tot 'n "samehang van sin", maar nog meer: binne die orde van die Kerkjaar bied dit die geleentheid tot die sinvolle vulling van tyd binne 'n breër samehang van sin. So het mense reeds van die vroegste tye bemoediging en heling deur die feeste van die Kerkjaar ervaar. Hierin het hulle Christus as hul arts en Heiland (in dié sin bedoel as "heler") ontmoet en is hulle in die helende (heilende) ritme van die Kerkjaar ingetrek. Hulle het in die ritme van die Kerkjaar geleef:

Und das war für sie ein gesunder Rhythmus. Die Feste haben ihre Zeit gegliedert und innen Anteil geschenkt an dem Geheimnis, dass Gott in diese Zeit gekommen ist und an den Festen immer wieder in unsere Zeit einbricht und sie aufhebt in die Ewigkeit. Für den, der Feste zu feiern versteht, wird jede Zeit sinnvoll erfüllte Zeit (Grün \& Reepen 1985:81).

As die "ritme van die tyd" (Harnoncourt \& Auf der Maur 1994:9-63) is die feesdae en seisoene van die Kerkjaar die polsslag waarmee die kerk van Christus lewe. Dit klop mee met die polsslag van gelowiges. Hierdie polsslag bied sekerheid en geborgenheid en gee uitdrukking aan mense se inherente sin vir tyd en orde. Die Kerkjaar gee struktuur binne die tyd, maar dit bied juis ook variasie en sorg dat dieselfde skriflesings, temas en liedere nie struktuurloos herhaal word nie. So word mens gevrywaar van eentonigheid(!) in die erediens:

Zo verstoren zij de monotonie en brengen de gedachtenis op gang. Wie telt is zich van de tijd bewust en van zijn plaats daarin (Monshouwer 1998:101).

Die ordelike strukturering van tyd en sinvolle vulling van die tyd werk vervreemding, verskeurdheid en gefragmenteerdheid teen. Dit bied ook 
beskerming teen verveling en meedoënloosheid. Dit bied oriëntering en sekerheid in die "Wiedererkennbaren" (Heimbrock 1993:79). As ons ons op die helende (heilenden) ritme van die Kerkjaar instel, leer ons onsself in ons hoogte en diepte ken: so kan ons hoop skep teenoor alle gevare wat ons bedreig en sal ons "Heilung finden von den vielen Wunden, die wir mit uns herumtragen" (Grün \& Reepen 1985:81-82). Die polsslag van die Kerkjaar bied die geleentheid om God se teenwoordigheid en sorg telkens weer deur die reeds-bekende te ervaar, maar ook om altyd op vele wyses nuut en opnuut daarvan bewus te word - en só self vernuwe te word. So funksioneer die Kerkjaar by uitstek pastoraal en helend.

\subsection{Die Kerkjaar het 'n gemeenskapsvormende of koinoniale funksie}

Gemeenskappeversekerdiekontinuïteitvanhulbestaan deurdie "ritmieserende diskontinuïteite" (Heimbrock 1993:67) van rituele en periodiek-terugkerende feeste. Groot feeste is geleenthede vir kollektiewe besinning. As sodanig is die feeste die plek vir die vorming van kulturele- en gemeenskapsidentiteit (Cornehl, Dutzmann \& Strauch 1993:9). Deur die fees word gemeenskap gevorm en word die gemeenskap versterk. ${ }^{4}$

Die erediens as die neergelegde vorm van die feestelike omgang met God en met mekaar, bied deur die jaar die geleentheid vir viering waardeur die gemeenskap van die gelowiges tot stand kom. In hierdie viering "versammeln sie sich zur Gemeinschaft des Volkes Gottes. Daher ist Christsein nahezu gleichbedeutend mit Sich-Versammeln (Ekklesia)" (Richter 1982:15).

The way Christians keep time is a way of remembering. In communal worship we remember and celebrate the events that make us who we are. Consequently the celebration of the Christian year forms us into Christ's body in the world (Saliers 1994: 92).

Die kollektiewe geheue van die geloofsgemeenskap word begrond deur, maar ook in stand gehou deur die heilsgebeure waaraan tydens erediensvierings binne die breër geheel van die Kerkjaar gestalte gegee word:

4 Die viering van Geloftedag binne gemeenskappe van Afrikaanssprekendes wat 'n sterk verbondenheid met die gebeure by Bloedrivier as konstitutief vir Afrikanerwees ervaar, is 'n voorbeeld van 'n periodiek-terugkerende fees waar kollektiewe herinnering deur bepaalde rituele aspekte lewend gehou word en waardeur die kulturele gemeenskap versterk word. 
In der gottesdienstlichen Feier der großen Jahresfeste verdichtet sich das kollektive Gedächtnis der religiösen Gemeinschaft an die sie begründenden Heilsereignisse (Assmann 1991:13-30).

Die viering van die erediens binne die Kerkjaar as "kollektiewe besinning in die tyd" vorm die identiteit van die geloofsgemeenskap (Brüske 2001:153). Die viering van die Kerkjaar is dus onontbeerlik vir die vorming en voortbestaan van die geloofsgemeenskap.

\subsection{Die Kerkjaar het 'n diakonale funksie}

'n Begrip wat tans oorgebruik en oorbelaai word, is die begrip "korporatiewe identiteit". Die begrip is egter baie relevant binne die kerk waar die handelende liggaam van Christus ter sprake is. Die korporatiewe identiteit van 'n kerk is die sigbare beeld wat 'n kerk deur haar lewe en werk ín die wêreld na buite kommunikeer. Die erediens vorm die uitgangspunt van alle kerkwerk:

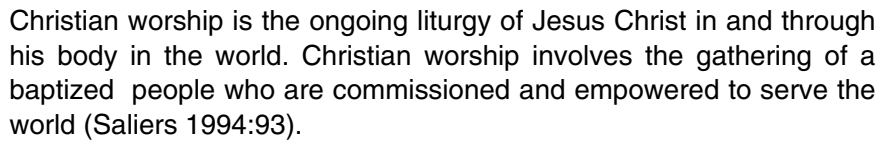

Die kerk leef en werk altyd vanuit en na die erediens toe - en elke erediens het ' $n$ plek binne die Kerkjaar. Die kerk se identiteit, die sigbare werk van die kerk, kan dus nooit los van die Kerkjaar staan nie. Dit behoort op alle vlakke konkreet gestalte te kry binne die Kerkjaar. In 'n bepaalde tyd in die Kerkjaar kan sekere temas wat met dié tyd verband hou ter sprake gebring word. In Epifanietyd, waar die doop van Jesus en sy optrede by Kana (dus as't ware sy "kinder- en jongmenstyd") ter sprake is, kan die sorg van kinders besondere aandag geniet. Om dieselfde rede is dit gepas om op Kersdag geskenke vir 'n kinderfonds te gee. In die Lydenstyd kan byvoorbeeld spesiale aandag gegee word aan mense wat deur siekte, armoede of op baie ander maniere ly. In die Opstandingstyd is aandag aan mense wat gesond geword het of nuwe geleenthede gekry het van pas. Gedurende die Pinksterkring kom die werk van die Heilige Gees en die uitdra van die Woord ter sprake. In Oktober word gefokus op die werk van die kerk in die breë - die werk van die Kerk in die wêreld en deur die ekumene. Gedurende Eskatologie, met die uitsien na die eindtyd, word besondere aandag gegee aan mense wat oud geword het. Op Ewigheidsondag, die laaste Sondag in die Kerkjaar, word mense wat geliefdes aan die dood afgestaan het, vertroos. Hierdie voorbeelde is slegs kursories. Daar is veel meer toepassingsmoontlikhede.

Vanuit die eredienste op die bepaalde Sondae in die Kerkjaar, waar die teologiese en geloofsperspektief op toepaslike kerklike en maatskaplike sake 
gegee word, word die werk van die kerk in die week verder voortgesit. So word die bewussyn vir die Kerkjaar in alle dimensies voortdurend lewend gehou en versterk. En so kom die volle rykdom van die Evangelie deur die handelende liggaam van Christus ook sigbaar in die wêreld tot uitdrukking.

\subsection{Die Kerkjaar het 'n missionêre funksie.}

Gelowiges kan die tye in die Kerkjaar só uitleef, dat buitestanders mense se geloof, of aspekte van die geloof, ook deur die gebruike en simbole van die spesifieke tye kan sien en ervaar. Heimbrock (1993:61) wys op die gebruik om in die privaatheid van die gesin die kerse op die Adventkrans aan te steek. So word met simboliese middele die "tyd uitdruklik gemaak", sigbaar gemaak: die brandende kerse dui op 'n duidelike begin en einde in die tyd. Dit is 'n gebruik wat standhou ondanks alle ontkerkliking en ritueelverarming.

Kersfees bied 'n verreikende missionêre geleentheid, alhoewel in 'n sekere sin 'n "geykte fees". Kranemann (1996:3-22) wys daarop dat dit juis die Sehnsucht na alternatiewe vir die algemene feeskultuur van die kommersiële wêreld is wat ook "kerkloses" met Kersfees na die kerk laat kom en dat daar byvoorbeeld onder die opskrif "Weihnachtslob für Ungläubige" die moontlikheid geopen moet word dat hierdie mense só kan deelkry aan die outentieke christelike feeskultuur.

Die Paassiklus bied ' $n$ besondere geleentheid wat meer gelééf behoort te word. Paasbolletjies, oftewel hot cross buns is dikwels vir oningewydes die aanknopingspunt en die eerste besef dat daar ' $n$ tyd is waar ' $n$ kruis van ongesuurde deeg op 'n broodjie besondere betekenis dra: verwysend na die kruis van Christus. Palmtakke in die kerke op Palmsondag, maar ook in huise die week daarná, is 'n sigbare teken vir besoekers aan dié huise.

Die gebruik in baie kerke om te vas en soberder te leef tydens die Lydenstyd, bring ook aan buitestanders 'n bewussyn van opoffering wat dui op die opoffering van die lydende Jesus. Dit is interessant hoe deelnemers aan karnavalle wêreldwyd, te midde van groot uitspattigheid, op televisie byvoorbeeld sal opmerk dat die karnaval die laaste geleentheid is om groot fees te vier, "want oor 'n dag of twee begin Lent." Veral in die lande waar die Katolieke kerk sterk is, soos Spanje en Suid-Amerika, is daar ' $n$ bewussyn vir die Veertigdagtyd oftewel Lent, selfs by mense wat op sigwaarde dalk geen erg aan die kerk het nie. Die bestaan van so 'n tyd vanweë die Kerkjaar bied dus 'n gespreksgeleentheid na mense sowel buite die kerk, as na dié binne die kerk vir wie kerkgang roetine geword het en wat vanuit so 'n skraal bewussyn vir die Kerkjaar leef, dat die Lydenstyd by hulle verbygaan - om nie eens te praat van die gebrekkige bewussyn vir Aswoensdag, die begin 
van die Lydenstyd, nie. Deur die karnavalvierders verneem "kerkmense" dikwels dat Lydenstyd voor die deur is!

\title{
3.9 Die Kerkjaar het 'n ekumeniese funksie.
}

Die Kerkjaar bind kerke oor die wêreld aan mekaar. Op dieselfde Sondag word wêreldwyd aan dieselfde temas van die geloof aandag gegee. Waar van leesroosters gebruik gemaak word, is die skriflesing oor kerk- en landsgrense dieselfde. Saliers (1994:92) verwys na "an unprecedented convergence across denominational lines ... on a basic theology of time represented in the new three-year lectionary." Liedere vir die tye in die jaar stem ook ver oor kerk- en landsgrense ooreen. Op 'n bepaalde tyd in die jaar klink dieselfde liedere oor die hele wêreld op.

Die Kerkjaar bring dus ' $n$ band tussen kerke oor die hele wêreld tot stand, wat elke Sondag en in die week deurlopend deur die jaar tot uiting kom. Dit bring selfs méér tot stand as groot ekumeniese organisasies wat van tyd tot tyd vergader en waar daar dikwels net gepráát word oor maniere om kerke aan mekaar te bind. Die Kerkjaar bied 'n deurlopende struktuur van éénheid deur die jaar - dit is die polsslag van gelowiges wat in die geloof sáám klop.

\section{SAMEVATTING: 'N PLEIDOOI VIR DIE KERKJAAR}

\begin{abstract}
Die Disposition des Kirchenjahres entlastet den Liturgen von der hoffnungslosen Anstrengung, alles Entscheidende auf einmal zu sagen oder immer etwas völlig Neues zu suchen, um die Gemeinde zu bewegen. Gerade dann wird die Gemeinde spüren, ob der Prediger außer Atem gerät, weil er aus dem Takt gekommen ist. Mag auch vielen Gemeindegliedern heutzutage das Kirchenjahr aus dem Bewußtsein entschwunden sein, so wird es um so wichtiger, dass die Theologen in inm leben (Sauter 1993:66 (My kursivering.)
\end{abstract}

Uit voorafgaande bespreking van die funksie en doel van die Kerkjaar is dit duidelik dat die Kerkjaar die viering, verkondiging, belydenis en vele ander funksies van die kerk onderlê. In die viering van die feeste deur die jaar kom die "volle waarheid van die Woord" ter sprake en word gelowiges in die gemeente en oor die hele wêreld saamgebind tot die gemeenskap van die liggaam van Christus. Die Kerkjaar is inderdaad 'n "flexibele hulpmiddel" en nie 'n "opgelegde keurslijf" nie (Monshouwer 1998:100). Uit voorafgaande blyk egter ook dat 'n verwaarlosing van die Kerkjaar of argelose omgang daarmee die geloofsgemeenskap in die breedste sin kan skaad: op die vlak van die verkondiging, viering, belydenis, kategese, koinonia, pastoraat, dienswerk, ekumene, missionaat - op elke vlak van die geloofsbelewing en 
geloofsuitlewing. Dit skaad ten diepste ook die individuele gelowige wie se geloofslewe uitmekaargeruk en gefragmenteer word.

Waarom sou 'n predikant of liturg die Kerkjaar ignoreer of slordig daarmee omgaan? Heimbrock (1993:74) se verhaal van die "frisch examinierte Vikar" (student) en sy evaluasie van dié se optrede bied myns insiens die sleutel. Hy vertel dat hierdie student hom met alle ywer op die "preekwerk" gestort het. Sy eerste poging was ' $n$ "geweldige", veels te lang preek. Hy het homself verontskuldig deur daarop te wys dat die moeilike teks dit vereis het. Dit was egter opvallend dat hierdie persoon dikwels laat was vir eredienste en ander byeenkomste. Die sistematiese uitleg van die Woord sou dan vir hom so belangrik wees, maar hy het die simboolinhoud van sy eie gedrag, sy "nieverbale minagting van tyd", sy "oorskryding van die norme van tyd", self nog nie opgemerk nie. Sy woordtaal en sy lyftaal het nie ooreengestem nie. Egte verkondiging het dus ontbreek. So het hy homself ook die reg veroorloof om die gemeente in die preek as't ware gevange te hou en hul tyd in oormaat in beslag te neem deur sy eie slordige hantering van tyd.

Die erediens is die viering van die tyd wat ons geskenk word - tyd is 'n gawe. 'n Mens moet tyd maak om aan God te dink (Heimbrock 1993:73). Predikante wat slordig met die Kerkjaar omgaan, verraai deur hul nie-verbale optrede dat hulle die geloof nie lééf nie; nié daagliks deur die jaar daarmee worstel nie; nié die erediens binne die breë geheel sien en hul diepgaande daarop voorberei nie; nie erns maak met die volheid van die openbaring nie; en bo alles die godgegewe tyd minag. Kan so iemand 'n oog hê vir die toekomstige tyd wat ons tegemoet tree en waarop ons ons voorberei?

'n Predikant se omgang met tyd en die wyse waarop hy/sy gestalte gee aan die kerk se feeste in die tyd, is 'n aanduiding van ' $n$ persoon se spiritualiteit (Saliers 1994:94). Dit verbaas nie dat predikante wat slordig met die Kerkjaar omgaan, dikwels hul preke net so uit preekbundels of van die internet neem - soms 'n Hervormingsondagpreek onveranderd vir Advent, 'n Palmsondagpreek in Epifanie, om nie te praat van 'n eskatologiepreek midde-in die Lydenstyd nie. So iemand se preke het vir die gemeente min te sê, omdat so 'n prediker nie geloof-waardig is nie. 'n Mens kan tog nie die ervaring van "geskenkte tyd" geloofwaardig en outentiek aan ander oordra as mens nie self bewustelik opmerksaam en keurig met God se tyd omgaan nie (Heimbrock 1993:79).

Ons hele lewe is tyd deur God geskenk. In die Kerkjaar gaan dit ten diepste oor 'n wyse waarop 'n mens die geskenkte tyd en jou geloof ten volle en sinvol kan uitleef; om in die helende ritme van die Kerkjaar die verlede teenwoordig te stel; om ons in die tyd ook op die jenseits van die tyd in te stel. Waar mense besondere tye in hul lewens in 'n eksistensiële sin ervaar en hulle bestaan in die tyd bewustelik inrig, word hulle oop vir die 
ervaring van tyd as gawe, as God se tyd. Sal ons die volheid van God en sy teenwoordigheid nie veel skerper in ons lewens ervaar as ons keurig met hierdie gawe omgaan nie?

\section{DANKWOORD}

Hiermee ' $n$ woord van dank aan prof Johan Janse van Rensburg vir die geleentheid oor jare om 'n bewussyn vir die Kerkjaar en die werking van die lied in ekumeniese verband, konkreet in breër kring te bevorder. Hy het in sy lewe en in sy akademiese werk getoon dat hy nie tevrede is met kompromieë, met die tweede beste nie. So ook in sy geloofslewe. Daardeur het hy hom getoon as iemand wat erns maak met die tyd as 'n gawe van God. Mag hy die tyd wat hom verder geskenk word met oorgawe gebruik om God te loof, sy skepping te geniet en dit in woord en kuns ook met ander te deel.

\section{BIBLIOGRAFIE}

\section{Assmann, J.} 1991. Der zweidimensionale Mensch. Das Fest als Medium des kollektiven Gedächtnisses. In: J. Assmann \& T. Sundermeier (Hg.), Das Fest und das Heilige. Religiöse Kontrapunkte zur Alltagswelt (Gütersloh: Gütersloher Verlagshaus), pp.13-30.

BAKKER, N. T. 1996. Geschiedenis in opspraak. Kampen: Kok

Barnard, M. 2006. Liturgie voorbij de Liturgische Beweging. Zoetermeer: Meinema.

BIERITZ, K-H. 2003. Ein Haus in der Zeit. In: H-CH. SCHMIDT-LAUBER, M. MEYER-BLANCK, K-H. BIERITZ (Hg.) Handbuch der Liturgik. 3. Auflage. (Göttingen: Vandenhoeck), pp. 355-390.

BRÜSKE, G.

2001. Die Liturgie als Ort des kulturellen Gedächtnisses. Anregungen für ein Gespräch zwischen Kulturwissenchaften un Liturgiewissenschaft. Liturgisches Jahrbuch 51: 151-171.

Cornehl, P., Dutzmann, M., Strauch, A. (Hg.)

1993. Vorwort. In: P. Cornehl, M. Dutzmann \& A. Strauch (Hg.), "In der Schar derer die da Feiern." Feste als Gegenstand praktisch-theologischer Reflexion. Göttingen: Vandenhoeck, 7-10.

DAIBER, K-F. 1992. Gottesdienst unter den Bedingungen der gegenwärtigen Gesellschaft. Für den Gottesdienst 39/40: 9-20. 
EAREY, M. \& MYers, G. 2001. Common Worship today: An illustrated guide to Common Worship. London: Harper Collins.

Grün, A. \& Reepen, M. 1985. Heilendes Kirchenjahr. Das Kirchenjahr als Psychodrama. Münsterschwarzach: Vier-Türme-Verlag.

HARNONCOURT, $P$. 1994. Feiern im Rhythmus der Zeit 2,1 In: Harnoncourt, P., Auf Der Maur, H., Meyer, H. B., Fischer, B. (Hrsg.) Gottesdienst der Kirche. Handbuch der Liturgiewissenchaft 6,1. (Regensburg: Pustet), pp. 9-63.

Heimbrock, $\mathrm{H}$.

1993. Gottesdienst: Spielraum des Lebens. Weinheim: Deutscher Studien Verlag.

Interkerkelijke Stichting Voor Het KerkLied. 1973. Liedboek voor de Kerken. Zoetermeer: Boekencentrum.

Klöckener, M. \& Kranemann, B. (Hrg.) 2002. Liturgiereformen. Historische Studien zu einem bleibenden Grundzug des christlichen Gottesdienstes. Teil II: Liturgiereformen seit der Mitte des 19. Jahrhunderts bis zur Gegenwart. Münster: Aschendorff.

KLOPPERS, E.C.

1997. Liturgiese musiek as ' $n$ kommunikatiewe handelinge in 'n postmoderne era. DTh-Proefskrif. UNISA.

2003a. Die invloed van 'n postmoderne tydsgees op die kerklied - enkele rigtingwysers. Nederduitse Gereformeerde Teologiese Tydskrif (NGTT) 44/ 3 \& 4: 320-329.

2003b. Die erediens as Gesamtkunstwerk. Nederduitse Gereformeerde Teologiese Tydskrif (NGTT) 44 / 1 \& 2: 80-88.

Kranemann, B.

1996. "Feiertags kommt das Vergessene ..." Zu Deutung und Bedeutung des christlichen Festes in moderner Gesellschafft. Liturgisches Jahrbuch 46: 3-22.

LITURGISCHE KONFERENZ 2005 Kirchenjahr erneuern Gottesdienstliche Praxis im Rhythmus des Jahreskreises. Hanover.

LONG, T. G.

2001. Beyond the Worship Wars. Building Vital and Faithful Worship. Washington: The Alban Institute.

LUTHER, M.

1983. Werke. Weimarer Ausgaben XXVI.

MönNICH, C.W.

1966. Antiliturgica. Amsterdam: Ten Have. 
MONSHOUWER, D. 1998. Sabbat en Sondag. In: P. Oskamp \& N. Schuman (reds.), De Weg van de liturgie: Tradities, achtergronden, praktijk (Zoetermeer: Meinema), pp. 99-124.

Nederduitse Gereformeerde Kerk 2007. Vir die Erediens - 'n handleiding. Wellington: Bybel-Media.

Nederduitsch Hervormde Kerk 2008. Diensboek. Pretoria: Sentik.

RICHTER, K. 1982. Was ich vom Kirchenjahr wissen wollte. Freiburg: Herder.

SALIERS, D. E. 1993. Worship as theology: Foretaste of glory divine. Nashville, TN: Abingdon. 1994. How the practice of the Christian year affects congregational life. In: R.E. Webber (ed.). The Services of the Christian Year. (Nashville TN: Star Song Publishing), pp. 92-94.

Sauter, G.

1993. "Kein Jahr von unserer Zeit verflieht, das dich nicht kommen sieht." Dogmatische Implikationen des Kirchenjahrs. In: P. Cornehl, M. Dutzmann, A. Strauch. (Hg.), "In der Schar derer die da Feiern." Feste als Gegenstand praktisch-theologischer Reflexion. (Göttingen: Vandenhoeck), pp. 56-68.

ScHILSON, A. 1994. Fest und Feier in anthropologischer und theologischer Sicht. Liturgisches Jahrbuch 44, 3-32.

Stichting Voor De KerkLied

1973. Liedboek voor de Kerken.

Van Leeuwen, M.

1998. Een weg in tijd en ruimte. In: P. Oskamp \& N. Schuman (red.), De Weg van de liturgie: Tradities, achtergronden, praktijk (Zoetermeer: Meinema), pp. 53-66.

Van Tongeren, L. 2001. Tijd. In: M. Barnard \& P. Post (red.), Ritueel bestek: Antropologische kernwoorden van de liturgie (Zoetermeer: Meinema), pp. 69-76.

WebBeR, R. E. (ED.) 1994. The Services of the Christian Year. Nashville TN: Star Song Publishing. The complete library of Christian worship, vol 5.

Trefwoorde

Kerkjaar

Liturgiese jaar

Erediens
Keywords

Church year

Liturgical year

Church service 